With this new volume of the $A r t$ Libraries Journal I take over from Philip Pacey as Editor. It is largely due to Philip's vision and dedication that the $A L J$ now reaches 40 different countries and features contributors from every continent. I look forward with enthusiasm - and some trepidation to maintaining the high standard the Journal has achieved, and to increasing its international content.

At the same time, as outgoing Chair of ARLIS/UK \& Ireland, I am proud that this quarterly, which has become such a world traveller, continues to be the professional journal produced by our Society. It is put together with the considerable help of an international team: Peter Trepanier of the National Gallery of Canada as Deputy Editor, and Sheila Klos, our new Reviews Editor, from the University of Oregon, as well as guest editors from many countries. We benefit from working closely with IFLA's Section of Art Libraries, a selection of whose Workshop and Open Forum papers is published, bringing the flavour of each year's conference to a far wider readership than could possibly hope to attend. And I would welcome suggestions for new volunteers and contributors from other parts of the globe.

It gives me particular pleasure to begin my Editorship of the Journal with some very varied papers from the IFLA Section of Art Libraries events held recently in Copenhagen, not least because they come from three of my favourite cities - Cape Town, Copenhagen and Paris. Josephine Andersen's account of her attempt to improve adult literacy, by combining her Library's facilities with the opportunities offered by the South African National Gallery's collections, will inspire and move readers as it did her audience in Denmark last August. And the two Danish papers in this issue describe a publishing initiative which is encouraging research into Scandinavian design (and the collecting of the resources which sustain such research) and the inauguration of a 'museum within a library' which will open to the public early in the next century, exhibiting a previously largely unknown collection of world-class photography.

Possible relationships between the artist and the art librarian are explored by JeanPaul Oddos and Lutz Jahre, who illustrate two very different ways of involving artists in the work of art libraries. And these papers are followed by a fascinating description of the impressive achievements of the Research Libraries Group in the States, and especially its Art \& Architecture Group, in extending access to the information which supports research and teaching in the fine and applied arts and architecture.

Circulated with this issue you will find a questionnaire which surveys various aspects of the $A L J$. Please spend a few moments giving us your views and suggestions so that the Journal can fulfil the expectations of you, the readers.

\section{Gillian Varley}

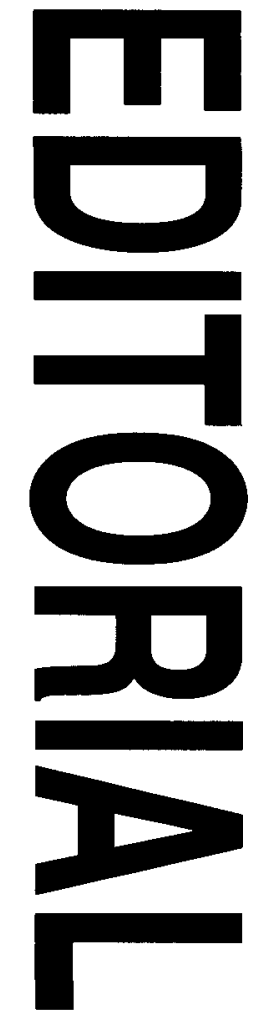

